\title{
PENERAPAN MODEL STAD BERBANTUAN MEDIA DATA INFORMASI DARI INTERNET UNTUK MENINGKATKAN KEMAMPUAN MENULIS TEKS BERITA
}

\author{
Agung Pramujiono, Fadhilah \\ Universitas PGRI Adi Buana Surabaya, SMPN 22 Surabaya \\ agungpramujiono@unipasby.ac.id \\ dhilah.dapuda@gmail.com \\ Diterima: 7 November 2018 \\ Publikasi: 27 Februari 2019 \\ DOI: http://dx.doi.org/10.32528/bb.v4i1.1863
}

\begin{abstract}
ABSTRAK
Penelitian ini bertujuan meningkatkan kemampuan menulis teks berita peserta didik kelas VIII-K SMPN 22 Surabaya melalui penerapan model STAD berbantuan media data informasi dari internet. Subjek penelitian ini adalah siswa kelas VIII-K yang berjumlah 38 orang. Lokasi penelitian di SMPN 22 Surabaya. Dalam PTK ini digunakan dua siklus yang masing-masing siklus terdiri atas tahap perencanaan, pelaksanaan, observasi-evaluasi, dan releksi. Dalam pengumpulan data digunakan teknik observasi dan tes, sedangkan analisis data dilakukan dengan menggunakan teknik deskriptif dan statistik deskriptif. Berdasarkan hasil observasi dapat diketahui bahwa dalam pelaksanaan PTK guru sudah melakukan aktivitas pembelajaran sesuai dengan rencana perbaikan pembelajaran. Berdasarkan hasil analisis data kuantitatif dapat diketahui rerata skor kemampuan menulis teks berita peserta didik menunjukkan adanya peningkatan. Pada kondisi awal rerata skor kemampuan menulis teks berita sebesar 77,33 dengan pencapaian KKM 68,42\%; siklus I rerata skor sebesar 84,98 pencapaian KKM sebesar 78,95\%; siklus II rerata skor sebesar $87,76 \%$ pencapaian KKM 100. Dengan demikian dapat disimpulkan penerapan model STAD berbantuan media data informasi dari internet dapat meningkatkan kemampuan menulis teks berita peserta didik kelas VIII-K SMPN 22 Surabaya.
\end{abstract}

Kata Kunci: model STAD, media data informasi dari internet, kemampuan menulis teks berita

\section{ABSTRACT}

This study was aimed at improving the ability to write news texts of the seventh-grade students through the implementation of the STAD model assisted by information from the internet as the instructional media. It was a classroom action research. The subjects of this study were 38 students of class VIII-K. The study was located at SMPN 22 Surabaya. It had two cycles in which each cycle consisted of the planning, implementation, observation-evaluation, and reflection phases. Observation and tests were utilized to collect the data; whereas the data analysis was carried out using the descriptive techniques and descriptive statistics. Based on the results of the observation it revealed that in the implementation of the action research the teacher carried out learning activities in accordance with the learning improvement plan. Based on the results of the quantitative data analysis, it indicated that the average score of the students' news text writing ability showed an increase. In the initial phase the average score of the news text writing skills was 77.33 with the achievement of the minimum criteria of mastery learning (known as KKM) reached $68.42 \%$. The first cycle average score was 84.98 with the KKM achievement of $78.95 \%$; the second cycle average score was $87.76 \%$ with the achievement of KKM of $100 \%$. It can thus be concluded that the application of the STAD model assisted by the internet-based information could improve the ability to write news text of class VIII-K students of SMP 22 Surabaya.

Keywords: STAD model, internet-based information, news text writing ability 
Jurnal Belajar Bahasa, ISSN 2502-5864, E-ISSN 2503-0329

Volume 4, No. 1, Februari 2019

\section{PENDAHULUAN}

Dalam pembelajaran

Bahasa

Indonesia di kelas VIII, teks berita diajarkan kepada peserta didik dengan Kompetensi Dasar (KD) sebagai berikut. KD 3.1 Mengidentifikasi unsur- unsur teks berita (membanggakan dan memotivasi) yang didengar; KD 3.2 Menelaah struktur dan kebahasaan teks berita (membanggakan dan memotivasi) yang didengar dan dibaca berita dan dibaca dan KD 4.1 Menyimpulkan isi dari berita (membanggakan dan memotivasi) yang dibaca dan didengar; KD 4.2 Menyajikan data, informasi dalam bentuk berita secara lisan dan tulis dengan memperhatikan struktur, kebahasaan, atau aspek lisan (lafal, intonasi, mimik, kinesik).

Dalam pembelajaran Bahasa Indonesia kelas VIII-K di SMPN 22 Surabaya ditemukan permasalahan peserta didik mengalami kesulitan dalam menulis teks berita. Permasalahan yang muncul di kelas tersebut berkaitan dengan KD 4.2 dengan indikator 4.2.2 Menyusun data dan informasi dalam bentuk berita secara tulis sesuai struktur dan kaidah kebahasaan. Rerata skor kemampuan menulis berita sebesar 77,33 masih di bawah KKM Bahasa Indonesia 80. Peserta didik yang telah mencapai KKM sebesar 68,42 .

Permasalahan ini ditemukan berdasarkan hasil observasi pembelajaran dan diskusi antara peneliti dengan guru mitra, Ibu Fadhilah. dalam program Penugasan Dosen di Sekolah PDS 2018. Berdasarkan hasil observasi yang dilakukan Rabu, 22 Agustus 2018 diketahui beberapa penyebab kesulitan belajar tersebut, yaitu (1) Peserta didik belum memahami hakikat berita. Hal ini tampak ketika mereka ditugasi untuk membawa berita dari koran, ada yang membawa surat pembaca; (2) Peserta didik masih belum memahami unsur berita; (3) Peserta didik masih mengalami kesulitan dalam memanfaatkan data berdasarkan sumber dari internet; (4) Peserta didik mengalami kesulitan dalam mengalimatkan informasi dalam teks berita; dan (5) Peserta didik mengalami kesulitan dalam menyusun koherensi teks. Kesulitan belajar tersebut perlu dipecahkan melalui penelitian tindakan kelas (PTK). Peneliti dan guru mitra mendiskusikan solusi yang dapat diterapkan guna memecahkan problem pembelajaran tersebut. Solusi yang dipilih adalah penerapan model Cooperatif Learning Tipe Student Teams Achievement Divisions (STAD) berbantuan media data informasi dari internet. Dipilih model STAD dengan pertimbangan bahwa dengan menerapkan model ini dapat memotivasi peserta didik untuk bekerja sama saling mendukung dan membantu dalam mencapai tujuan pembelajaran (Slavin, 2008). Menurut Slavin (2008), model STAD sudah banyak diterapkan dalam pelajaran matematika, bahasa, seni, Ilmu Pengetahuan Sosial, dan IImu Pengetahuan Alam. Mulai pendidikan dasar sampai pendidikan tinggi. Mereka bekerja secara berkelompok mendiskusikan target pembelajaran yang akan dicapai dan saling membantu dalam pemecahan masalah belajar.

Berdasarkan kajian empiris dapat diketahui bahwa di Indonesia model STAD 
juga sudah diterapkan mulai pendidikan dasar sampai perguruan tinggi dan terbukti mampu membantu para guru dan dosen memecahkan masalah pembelajaran di kelas. Sumarni dan Susanti (2016) menerapkan model STAD untuk meningkatkan hasil belajar mahasiswa pada matakuliah perencanaan pembelajaran ekonomi; Elisa, Matsum, dan Warneri (2015) menerapkan Model STAD untuk meningkatkan hasil belajar siswa IX AK SMK; Hastuti (2017) menerapkan model pembelajaran kooperatif tipe Student TeamsAchievement Division (STAD) untuk meningkatkan kemampuan berpendapat siswa pada mata pelajaran bahasa Indonesia kelas IV SD. Dengan demikian pemilihan pemecahan masalah menggunakan Model STAD untuk meningkatkan kemampuan menulis berita mendapatkan penguatan secara empiris.

Model STAD merupakan salah satu tipe model Pembelajaran Kooperatif. Dalam pembelajaran kooperatif ditekankan kerja sama antarpeserta didik untuk mencapai tujuan pembelajaran. Arends (1997) lihat juga Suyanto dan Jihad (2013) menjelaskan bahwa model kooperatif memiliki karakteristik sebagai berikut. (1) Peserta didik bekerja secara berkelompok untuk menuntaskan materi yang dipelajari; (2) Tim masing-masing kelompok terdiri atas siswa-siswa yang memiliki kemampuan tinggi, sedang, dan rendah; (3) Jika dimungkinkan kelompok yang dibentuk terdiri atas beberapa ras, suku, budaya, jenis kelamin yang berbeda; (4) Penghargaan atas keberhasilan belajar lebih diutamakan pada kerja kelompok daripada perorangan.

Sintaks Pembelajaran Kooperatif tipe STAD adalah sebagai berikut. (1) Menyampaikan tujuan dan memotivasi siswa. Pada tahap ini guru menginformasikan tujuan pembelajaran yang akan dicapai dan memotivasi siswa. (2) Menyajikan informasi. Pada tahap ini guru menyajikan informasi kepada siswa dengan jalan mendemonstrasikan atau memberikan bahan bacaan.

Mengorganisasikan peserta didik dalam kelompok-kelompok belajar. Pada tahap ini, guru membentuk kelompok belajar dengan memperhatikan keragaman latar siswa dan membantu setiap kelompok agar melakukan perpindahan secara efisien. (4) Membimbing kelompok bekerja dan belajar. Pada tahap ini, guru membimbing kelompok ketika mereka menyelesaikan tugas. (5) Melakukan evaluasi. Pada tahap ini, guru mengevaluasi hasil belajar dengan memberikan kesempatan kepada masingmasing kelompok untuk mempresentasikan hasil kerja kelompok dan kelompok lain memberikan tanggapan; dan (5) Memberikan penghargaan. Guru mencari cara-cara untuk menghargai baik upaya maupun hasil belajar individu dan kelompok (Nur, 2005; Trianto, 2009).

Dalam pembelajaran Bahasa Indonesia di kelas VIII, teks berita diajarkan kepada peserta didik. Berita merupakan laporan suatu kejadian atau peristiwa. Dalam berita dimuat informasi-informasi detil suatu kejadian atau peristiwa yang tidak kita ketahui. Kusumaningrat dan Kusumaningrat (2006:40) mendefiniskan 
berita sebagai informasi aktual tentang fakta-fakta dan opini yang menarik perhatian orang. Lebih lanjut dijelaskan berita dimulai dengan ringkasan atau klimaks dalam paragraf pembukanya, kemudian dikembangkan lebih lanjut dalam paragraf selanjutnya dengan memberikan rincian secara kronologis atau dalam urutan yang semakin menurun daya tariknya. Bagian awal disebut sebagai lead (teras berita) dan yang memuat rincian disebut sebagai tubuh berita (Kusumaningrat dan Kusumaningrat, 2006:126). Teras berita yang baik mengandung unsur $5 \mathrm{~W}+1 \mathrm{H}$ (what, where, when,who, why + how) yang sering diakronimkan sebagai adiksimba.

Permasalahan pembelajaran di kelas VIII-K SMPN 22 Surabaya berkaitan dengan kemampuan menulis teks berita perlu segera mendapatkan penyelesaian sehingga dilakukan penelitian tindakan kelas. Masalah penelitian dirumuskan sebagai berikut. Apakah penerapan model STAD berbantuan media data informasi dari internet dapat meningkatkan kemampuan menulis berita peserta didik kelas VIII-K SMPN 22 Surabaya? Adapun tujuan penelitian ini adalah untuk meningkatkan kemampuan menulis berita peserta didik kelas VIII-K SMPN 22 Surabaya melalui penerapan model STAD berbantuan media data informasi dari internet. Indikator keberhasilan dalam PTK ini adalah jika rerata skor kemampuan menulis teks berita peserta didik mencapai KKM 80 dengan persentase capaian $85 \%$. Melalui penelitian ini diharapkan dapat membantu guru mengatasi problematik aktual yang terjadi di kelas dan meningkatkan kinerja guru melalui kolabarosi penelitian dan penulisan karya ilmiah.

\section{METODE PENELITIAN}

Penelitian ini merupakan penelitian tindakan kelas (PTK). Menurut Pramujiono (2010), PTK dapat digunakan untuk mengatasi berbagai permasalahan pembelajaran yang muncul dalam praktik pembelajaran di kelas. Dalam penelitian ini dilakukan dua siklus, masing-masing siklus terdiri atas tahap perencanaan (plan), pelaksanaan (do), observasi-evaluasi (observation-evaluation), dan refleksi (reflection). Subjek penelitian ini adalah peserta didik kelas VIII-K SMPN 22 Surabaya sebanyak 38 orang. SMPN 22 Surabaya terletak di Jln. Gayungsari Barat X No.38 Kec. Gayungan Surabaya. Lingkungan sekolah sangat kondusif untuk pelaksanaan kegiatan belajar mengajar.

Teknik pengumpulan data yang digunakan adalah observasi dan tes menulis berita. Teknik observasi digunakan untuk mengumpulkan data kualitatif berupa fenomena yang terjadi ketika kegiatan belajar mengajar berlangsung, sedangkan tes digunakan untuk mengumpulkan data kuantitatif berkaitan dengan kemampuan menulis teks berita. Teks berita dinilai dengan indikator: (1) kelengkapan struktur teks berita, (2) kemenarikan rumusan judul, (3) kelengkapan informasi yang disajikan, (4) kebakuan penggunaan diksi dan kalimat, (5) Kohesi dan koherensi teks, 
dan (6) Penggunaan Ejaan. Teknik penganalisisan data yang digunakan adalah teknik deskriptif untuk menganalisis data kualitatif, dan teknik statistik deskriptif untuk menganalisis data kuantitatif khususnya untuk menghitung persentase dan rerata.

\section{PEMBAHASAN}

Siklus I dilaksanakan dalam dua pertemuan. Pertemuan ke-1, Rabu, 29 Agustus 2018 bertempat di Laboratorium Komputer dan pertemuan ke-2 Kamis, 30 September 2018 bertempat di kelas VIII-K. Pelaksanaan pembelajaran pada siklus I dideskripsikan sebagai berikut. Pada pertemuan ke-1, aktivitas yang dilakukan oleh guru adalah sebagai berikut. (1) Guru membuka pelajaran dengan memberi salam dan menjelaskan tujuan pembelajaran yang akan dicapai. (2) Guru mengajak peserta didik untuk mendengarkan lagu wajib Indonesia pusaka. (3) Guru memotivasi siswa akan pentingnya mencari informasi di era revolusi industry 4.0. (4) Guru menjelaskan langkah-langkah pembelajaran yang akan dilakukan. (5) Guru membagi kelas dalam delapan kelompok yang masing-masing terdiri atas empat orang kemudian memberi label dengan nama koran atau stasiun televisi. (6) Masing-masing kelompok menggunakan PC yang ada di Laboratorium untuk mencari data informasi peristiwa gempa di Lombok. Ketika peserta didik mengerjakan tugas, guru keliling ruang untuk membantu kelompok yang mengalami kesulitan. Setelah setiap kelompok menemukan informasi, guru bersama peserta didik menyepakati salah satu sumber data yang dinilai memberikan informasi paling lengkap tentang peristiwa gempa di Lombok. (7) Guru menugasi setiap kelompok untuk menyusun teks berita berdasarkan sumber informasi yang telah disepakati dan mengingatkan peserta didik tentang kelengkapan struktur teks berita, kebakuan penggunaan kata dan kalimat, kohesi-koherensi teks, dan penggunaan ejaan. (8) Guru mengakhiri pelajaran dengan mengingatkan kembali tugas yang harus diselesaikan oleh masingmasing kelompok.

Pertemuan ke-2 siklus I bertempat di kelas VIII-K. Aktivitas yang dilakukan oleh guru adalah sebagai berikut. (1) Guru membuka pelajaran dengan memberi salam dan menjelaskan tujuan pembelajaran yang akan dicapai. (2) Guru mengajak peserta didik untuk mendengarkan lagu wajib Indonesia pusaka. (3) Guru menjelaskan langkah-langkah pembelajaran yang akan dilakukan. (4) Guru meminta perwakilan kelompok untuk membacakan teks berita yang ditulis pada pertemuan ke-1 dan meminta kelompok lain memberikan tanggapan berkaitan dengan enam indikator penilaian teks berita. (5) Guru meminta setiap kelompok menyunting teks berita dan mengumpulkannya setelah selesai. (6) 
Agung Pramujiono, Fadhilah. Penerapan Model STAD Berbantuan....

Jurnal Belajar Bahasa, ISSN 2502-5864, E-ISSN 2503-0329

Volume 4, No. 1, Februari 2019

Guru memberikan penghargaan dan hasil belajar yang telah dicapai terhadap hasil kerja kelompok dengan oleh peserta didik.

mendengarkan bersama lagu Butet Adapun hasil penilaian menulis yang berasal dari daerah Batak. (7) teks berita pada siklus I disajikan Guru mengakhiri pelajaran dengan dalam tabel 1 berikut.

mereviu pelaksanaan pembelajaran

Tabel 1. Skor Hasil Penilaian Menulis Teks Berita Siklus I

\begin{tabular}{|c|c|c|c|c|c|c|c|c|c|}
\hline \multirow{2}{*}{ NO } & \multirow{2}{*}{$\begin{array}{c}\text { NO } \\
\text { INDUK }\end{array}$} & \multirow{2}{*}{$\mathrm{L} / \mathrm{P}$} & \multicolumn{6}{|c|}{ SKOR PER ASPEK } & \multirow{2}{*}{ Skor Total } \\
\hline & & & A & $\mathrm{B}$ & $C$ & $\mathrm{D}$ & $\mathrm{E}$ & $\mathrm{F}$ & \\
\hline 1 & 11743 & $\mathrm{~L}$ & 90 & 75 & 75 & 80 & 75 & 80 & 79,17 \\
\hline 2 & 11744 & $P$ & 90 & 90 & 90 & 90 & 85 & 90 & 89,17 \\
\hline 3 & 11745 & L & 80 & 85 & 90 & 85 & 80 & 80 & 83,33 \\
\hline 4 & 11746 & $P$ & 90 & 90 & 95 & 90 & 90 & 90 & 90,83 \\
\hline 5 & 11747 & $\mathrm{~L}$ & 80 & 85 & 90 & 85 & 80 & 80 & 83,33 \\
\hline 6 & 11748 & $P$ & 90 & 90 & 95 & 90 & 90 & 90 & 90,83 \\
\hline 7 & 11749 & L & 80 & 85 & 90 & 85 & 80 & 80 & 83,33 \\
\hline 8 & 11750 & $P$ & 90 & 90 & 90 & 85 & 80 & 85 & 86,67 \\
\hline 9 & 11751 & $P$ & 80 & 85 & 90 & 85 & 80 & 80 & 83,33 \\
\hline 10 & 11752 & $P$ & 90 & 85 & 75 & 85 & 80 & 80 & 82,50 \\
\hline 11 & 11753 & $P$ & 90 & 85 & 75 & 85 & 80 & 80 & 82,50 \\
\hline 12 & 11754 & L & 75 & 75 & 80 & 75 & 75 & 75 & 75,83 \\
\hline 13 & 11755 & $\mathrm{~L}$ & 90 & 85 & 75 & 85 & 80 & 80 & 82,50 \\
\hline 14 & 11756 & $\mathrm{~L}$ & 90 & 85 & 75 & 85 & 80 & 80 & 82,50 \\
\hline 15 & 11757 & L & 90 & 90 & 90 & 90 & 90 & 85 & 89,17 \\
\hline 16 & 11758 & L & 90 & 90 & 90 & 90 & 80 & 85 & 87,50 \\
\hline 17 & 11759 & $P$ & 90 & 90 & 90 & 90 & 80 & 85 & 87,50 \\
\hline 18 & 11760 & $P$ & 90 & 90 & 90 & 85 & 80 & 85 & 86,67 \\
\hline 19 & 11761 & $P$ & 80 & 85 & 90 & 85 & 80 & 80 & 83,33 \\
\hline 20 & 11762 & $P$ & 90 & 90 & 90 & 90 & 80 & 85 & 87,50 \\
\hline 21 & 11763 & $P$ & 90 & 90 & 90 & 90 & 85 & 90 & 89,17 \\
\hline 22 & 11764 & $\mathrm{~L}$ & 90 & 90 & 90 & 90 & 90 & 85 & 89,17 \\
\hline 23 & 11765 & L & 75 & 75 & 80 & 75 & 75 & 75 & 75,83 \\
\hline 24 & 11766 & L & 75 & 75 & 80 & 75 & 75 & 75 & 75,83 \\
\hline 25 & 11767 & L & 90 & 90 & 90 & 90 & 90 & 85 & 89,17 \\
\hline 26 & 11768 & $P$ & 90 & 90 & 95 & 90 & 90 & 90 & 90,83 \\
\hline 27 & 11769 & $P$ & 90 & 90 & 90 & 90 & 90 & 85 & 89,17 \\
\hline 28 & 11770 & L & 75 & 75 & 80 & 75 & 75 & 75 & 75,83 \\
\hline 29 & 11771 & $P$ & 90 & 90 & 90 & 85 & 80 & 85 & 86,67 \\
\hline 30 & 11772 & L & 90 & 75 & 75 & 80 & 75 & 80 & 79,17 \\
\hline 31 & 11773 & $P$ & 90 & 90 & 90 & 90 & 80 & 85 & 87,50 \\
\hline 32 & 11774 & $P$ & 90 & 75 & 75 & 80 & 75 & 80 & 79,17 \\
\hline
\end{tabular}


Jurnal Belajar Bahasa, ISSN 2502-5864, E-ISSN 2503-0329

Volume 4, No. 1, Februari 2019

\begin{tabular}{rrrrrrrrrr}
33 & 11775 & $\mathrm{P}$ & 90 & 90 & 90 & 85 & 80 & 85 & 86,67 \\
34 & 11776 & $\mathrm{P}$ & 90 & 90 & 90 & 90 & 85 & 90 & 89,17 \\
35 & 11777 & $\mathrm{P}$ & 90 & 90 & 90 & 90 & 85 & 90 & 89,17 \\
36 & 11778 & $\mathrm{P}$ & 90 & 90 & 95 & 90 & 90 & 90 & 90,83 \\
37 & 11781 & $\mathrm{P}$ & 90 & 90 & 90 & 90 & 90 & 85 & 89,17 \\
38 & 11782 & $\mathrm{~L}$ & 90 & 75 & 75 & 80 & 75 & 80 & 79,17 \\
\hline & JUMLAH & & 3310 & 3255 & 3280 & 3255 & 3110 & 3165 & 3229,17 \\
& RERATA & & 87,1 & 85,66 & 86,32 & 85,66 & 81,84 & 83,30 & 84,98 \\
\hline
\end{tabular}

Keterangan:

$\mathrm{A}=$ Kelengkapan struktur berita; $\mathrm{B}=$ Kemenarikan Judul; $\mathrm{C}=$ Detil sajian informasi; $D=$ Kebakuan penggunan kata dan kalimat; $E=$ Kohesi dan koherensi teks; F: Penggunaan Ejaan

Berdasarkan tabel 1 di atas dapat diketahui rerata kemampuan menyusun teks berita pada siklus I sebesar 84,98. Rerata aspek kelengkapan stuktur teks berita sebesar 87,1. Rerata kemenarikan judul sebesar 85,66 . Rerata detil sajian informasi 86,32. Rerata kebakuan kata dan kalimat sebesar 85,66. Rerata kohesi dan koherensi teks sebesar 81,84 . Rerata penggunaan ejaan sebesar 83,30 .

Berdasarkan hasil refleksi pelaksanaan siklus I dapat dikemukakan kekuatan dan kelemahan sebagai berikut. Kekuatan pelaksanaan siklus I adalah (1) Guru sudah melaksanakan pembelajaran sesuai dengan skenario yang dirancang. (2) Peserta didik mempunyai rasa ingin tahu yang besar untuk mencari sumber data informasi dari internet. (3) Peserta didik mampu bekerja sama dan berkolaborasi dalam tim. (4) Peserta didik mampu berbagi tugas dalam menyelesaikan masalah.
Hal-hal yang menjadi catatan sebagai kelemahan dalam pelaksanaan pertemuan ke-1 dan ke-2 siklus I adalah sebagai berikut. (1) PC di laboratorium komputer ternyata tidak dilengkapi dengan program Microsoft office sehingga peserta didik mengalami kesulitan ketika menyimpan data yang diperoleh dari hasil unduh di intenet. (2) Ketika mengunduh informasi dari internet ada peserta didik yang membuka laman yang tidak gayut dengan tugas yang harus dikerjakan. (3) Peserta didik kesulitan menyusun kalimat kompleks yang di dalamnya mengandung konjungsi yang sebagai pembentuk klausa relatif sebagai atribut frase. (4) Peserta didik belum cermat dalam menggunakan ragam bahasa baku dan dalam menggunakan ejaan.

Untuk mengatasi kelemahan pada siklus I, dalam pelaksanaan siklus II akan dilakukan hal-hal sebagai berikut. (1) Penelusuran sumber data tidak menggunakan komputer di 
laboratorium tetapi menggunakan HP. (2) Guru akan lebih mengawasi aktivitas yang dilakukan oleh peserta didik. (3) Guru perlu memberikan penyegaran kepada peserta didik tentang penggunaan kata baku dan kalimat efektif.

Siklus II dilaksanakan dalam dua kali pertemuan. Pertemuan ke-1 Rabu, 5 September 2018 dan pertemuan ke2 Kamis, 6 September 2018 bertempat di kelas VIII-K. Aktivitas guru dalam pelaksanaan siklus II pertemuan ke-1 adalah sebagai berikut. (1) Guru membuka pelajaran dengan memberi salam dan menjelaskan tujuan pembelajaran yang akan dicapai. (2) Guru mengajak peserta didik untuk mendengarkan lagu Meraih Bintang Via Vallen sebagai motivasi. (3) Guru memberikan evaluasi pelaksanaan pembelajaran sebelumnya dalam siklus I. (4) Guru menjelaskan langkah-langkah pembelajaran yang akan dilakukan. (5) Guru meminta peserta didik untuk duduk sesuai dengan kelompoknya. (6) Guru memberikan penjelasan tentang kata baku dan kalimat efektif kemudian menugasi peserta didik untuk mencari data informasi tentang Asean Games 2018 melalui HP. (7) Masing-masing kelompok menggunakan HP untuk mencari data informasi tentang Asean Games 2018. Ketika peserta didik mengerjakan tugas, guru keliling ruang untuk membantu kelompok yang mengalami kesulitan. (8) Setelah setiap kelompok menemukan informasi, guru menugasi setiap kelompok untuk menyusun teks berita berdasarkan sumber informasi yang diperoleh. Di sini peserta didik diberi kebebasan untuk memilih sumber data informasi. Guru kembali mengingatkan peserta didik tentang kelengkapan struktur teks berita, penggunaan kata baku dan kalimat efektif, kohesi-koherensi teks, dan kecermatan dalam menggunakan ejaan. (8) Guru mengakhiri pelajaran dengan mengingatkan kembali tugas yang harus diselesaikan oleh masingmasing kelompok.

Pertemuan ke-2 siklus II bertempat di kelas VIII-K. Aktivitas yang dilakukan oleh guru adalah sebagai berikut. (1) Guru membuka pelajaran dengan memberi salam dan menjelaskan tujuan pembelajaran yang akan dicapai. (2) Guru mengajak peserta didik untuk mendengarkan lagu wajib Indonesia pusaka. (3) Guru menjelaskan langkah-langkah pembelajaran yang akan dilakukan. (4) Guru meminta perwakilan kelompok untuk membacakan teks berita yang ditulis pada pertemuan ke-1 dan meminta kelompok lain memberikan tanggapan berkaitan dengan enam indikator penilaian teks berita. (5) Guru meminta setiap kelompok menyunting teks berita dan mengumpulkannya setelah selesai. (6) Guru memberikan penghargaan terhadap hasil kerja kelompok dengan mendengarkan bersama lagu Yamko Rambe Yamko yang berasal dari daerah Papua. (7) Guru mengakhiri pelajaran dengan mereviu 
Agung Pramujiono, Fadhilah. Penerapan Model STAD Berbantuan....

Halaman 1-14

Jurnal Belajar Bahasa, ISSN 2502-5864, E-ISSN 2503-0329

Volume 4, No. 1, Februari 2019

pelaksanaan pembelajaran dan hasil

Hasil penilaian menulis teks berita

belajar yang telah dicapai oleh peserta pada siklus II disajikan dalam tabel 2 didik.

berikut.

Tabel 2. Skor Hasil Penilaian Menulis Teks Berita Siklus II

\begin{tabular}{|c|c|c|c|c|c|c|c|c|c|}
\hline \multirow{2}{*}{ NO } & \multirow{2}{*}{ NO INDUK } & \multirow{2}{*}{$L / P$} & \multicolumn{6}{|c|}{ SKOR PER ASPEK } & \multirow{2}{*}{ Skor Total } \\
\hline & & & $\mathrm{A}$ & $\mathrm{B}$ & $\mathrm{C}$ & $\mathrm{D}$ & $\mathrm{E}$ & $\mathrm{F}$ & \\
\hline 1 & 11743 & $\mathrm{~L}$ & 90 & 85 & 85 & 75 & 80 & 80 & 82,5 \\
\hline 2 & 11744 & $P$ & 95 & 95 & 95 & 95 & 85 & 95 & 93,33 \\
\hline 3 & 11745 & $\mathrm{~L}$ & 90 & 90 & 90 & 85 & 85 & 80 & 88,33 \\
\hline 4 & 11746 & $P$ & 90 & 95 & 95 & 90 & 90 & 90 & 91,67 \\
\hline 5 & 11747 & $\mathrm{~L}$ & 90 & 90 & 90 & 85 & 85 & 80 & 88,33 \\
\hline 6 & 11748 & $\mathrm{P}$ & 95 & 95 & 95 & 90 & 90 & 90 & 91,67 \\
\hline 7 & 11749 & $\mathrm{~L}$ & 90 & 90 & 90 & 85 & 85 & 80 & 88,33 \\
\hline 8 & 11750 & $P$ & 90 & 90 & 80 & 85 & 80 & 90 & 85,83 \\
\hline 9 & 11751 & $P$ & 90 & 90 & 90 & 85 & 85 & 80 & 88,33 \\
\hline 10 & 11752 & $P$ & 90 & 85 & 80 & 85 & 80 & 85 & 84,17 \\
\hline 11 & 11753 & $\mathrm{P}$ & 90 & 85 & 80 & 85 & 80 & 85 & 84,17 \\
\hline 12 & 11754 & $\mathrm{~L}$ & 90 & 90 & 85 & 80 & 85 & 80 & 85 \\
\hline 13 & 11755 & $\mathrm{~L}$ & 90 & 85 & 80 & 85 & 80 & 85 & 84,17 \\
\hline 14 & 11756 & $\mathrm{~L}$ & 90 & 85 & 80 & 85 & 80 & 85 & 84,17 \\
\hline 15 & 11757 & $\mathrm{~L}$ & 90 & 95 & 90 & 90 & 90 & 85 & 90 \\
\hline 16 & 11758 & $\mathrm{~L}$ & 95 & 90 & 95 & 85 & 80 & 85 & 88,33 \\
\hline 17 & 11759 & $\mathrm{P}$ & 95 & 90 & 95 & 90 & 80 & 85 & 88,33 \\
\hline 18 & 11760 & $P$ & 90 & 90 & 80 & 85 & 80 & 90 & 85,83 \\
\hline 19 & 11761 & $\mathrm{P}$ & 90 & 90 & 90 & 85 & 85 & 80 & 88,33 \\
\hline 20 & 11762 & $\mathrm{P}$ & 95 & 90 & 95 & 90 & 80 & 85 & 88,33 \\
\hline 21 & 11763 & $\mathrm{P}$ & 95 & 95 & 95 & 95 & 85 & 95 & 93,33 \\
\hline 22 & 11764 & $\mathrm{~L}$ & 90 & 95 & 90 & 90 & 90 & 85 & 90 \\
\hline 23 & 11765 & $\mathrm{~L}$ & 90 & 90 & 85 & 80 & 85 & 80 & 85 \\
\hline 24 & 11766 & $\mathrm{~L}$ & 90 & 90 & 85 & 80 & 85 & 80 & 85 \\
\hline 25 & 11767 & $\mathrm{~L}$ & 90 & 95 & 90 & 90 & 90 & 85 & 90 \\
\hline 26 & 11768 & $P$ & 95 & 95 & 95 & 90 & 90 & 90 & 91,67 \\
\hline 27 & 11769 & $P$ & 90 & 95 & 90 & 90 & 90 & 85 & 90 \\
\hline 28 & 11770 & $\mathrm{~L}$ & 90 & 90 & 85 & 80 & 85 & 80 & 85 \\
\hline 29 & 11771 & $P$ & 90 & 90 & 80 & 85 & 80 & 90 & 85,83 \\
\hline 30 & 11772 & $\mathrm{~L}$ & 90 & 85 & 85 & 75 & 80 & 80 & 82,5 \\
\hline 31 & 11773 & $P$ & 95 & 90 & 95 & 90 & 80 & 85 & 88,33 \\
\hline 32 & 11774 & $\mathrm{P}$ & 90 & 85 & 85 & 75 & 80 & 80 & 82,5 \\
\hline 33 & 11775 & $\mathrm{P}$ & 90 & 90 & 80 & 85 & 80 & 90 & 85,83 \\
\hline 34 & 11776 & $\mathrm{P}$ & 95 & 95 & 95 & 95 & 85 & 95 & 93,33 \\
\hline 35 & 11777 & $\mathrm{P}$ & 95 & 95 & 95 & 95 & 85 & 95 & 93,33 \\
\hline 36 & 11778 & $P$ & 95 & 95 & 95 & 90 & 90 & 90 & 91,67 \\
\hline
\end{tabular}


Agung Pramujiono, Fadhilah. Penerapan Model STAD Berbantuan....

Jurnal Belajar Bahasa, ISSN 2502-5864, E-ISSN 2503-0329

Volume 4, No. 1, Februari 2019

\begin{tabular}{cccccccccc}
37 & 11781 & $\mathrm{P}$ & 90 & 95 & 90 & 90 & 90 & 85 & 90 \\
38 & 11782 & $\mathrm{~L}$ & 90 & 85 & 85 & 75 & 80 & 80 & 82,5 \\
\hline & JUMLAH & & 3475 & 3445 & 3360 & 3270 & 3195 & 3245 & 3335,00 \\
& RERATA & & 91,45 & 90,66 & 88,42 & 86,05 & 84,08 & 85,40 & 87,76 \\
\hline
\end{tabular}

Keterangan:

$A=$ Kelengkapan unsur berita; $B=$ Kemenarikan Judul; $C=$ Detil sajian informasi; $D=$ Kebakuan penggunan kata dan kalimat; $E=$ Kohesi dan koherensi teks; F: Penggunaan Ejaan

Berdasarkan tabel 2 di atas dapat diketahui rerata kemampuan menyusun teks berita pada siklus II sebesar 87,76. Rerata aspek kelengkapan struktur teks berita sebesar 91,45. Rerata kemenarikan judul sebesar 90.66. Rerata detil sajian informasi 86,32. Rerata kebakuan penggunaan kata dan kalimat sebesar 86,05 . Rerata kohesi dan koherensi teks sebesar 84,08. Rerata penggunaan ejaan sebesar 85,40 .

Perkembangan skor hasil penilaian menulis teks berita siklus I dan siklus II disajikan dalam tabel 3 berikut.

Tabel 3. Perkembangan Skor Hasil Penilaian Menulis Teks Berita Siklus I dan Siklus II

\begin{tabular}{clccc}
\hline NO & \multicolumn{1}{c}{ Indikator Penilaian } & SIKLUS I & SIKLUS II & KETERANGAN \\
\hline 1 & Kelengkapan Struktur Teks Berita & 87,10 & 91,45 & Naik \\
2 & Kemenarikan Judul & 85,66 & 90,66 & Naik \\
3 & Detil Sajian Informasi & 86,32 & 88,42 & Naik \\
4 & Kebakuan Kata dan Kalimat & 85,66 & 86,05 & Naik \\
5 & Kohesi dan Koherensi Teks & 81,84 & 84,08 & Naik \\
6 & Penggunaan Ejaan & 83,29 & 85,4 & Naik \\
7 & Rerata Kumulatif Skor & 84,98 & 87,76 & Naik
\end{tabular}

Dari tabel 3 dapat diketahui untuk indikator kelengkapan struktur teks berita pada siklus I rerata sebesar 87,10 pada siklus II 91,45 terdapat kenaikan 4,35; untuk indikator kemenarikan judul pada siklus I rerata sebesar 85,66 pada siklus II 90,66 terdapat kenaikan 5,0; untuk indikator detil sajian informasi pada siklus I rerata sebesar 86,32 pada siklus II 88,42 terdapat kenaikan 2,1; untuk indikator kebakuan kata dan kalimat pada siklus I rerata sebesar 85,66 pada siklus II 86,05 terdapat kenaikan 0,39 ; untuk indikator kohesi dan koherensi teks pada siklus I rerata sebesar 81,84 pada siklus II 84,08 terdapat kenaikan 2,24; untuk indikator penggunaan ejaan pada siklus I rerata sebesar 81,84 pada siklus II 84,08 terdapat kenaikan 2,24. Rerata kumulatif skor pada siklus I 
Agung Pramujiono, Fadhilah. Penerapan Model STAD Berbantuan....

Jurnal Belajar Bahasa, ISSN 2502-5864, E-ISSN 2503-0329

Volume 4, No. 1, Februari 2019

sebesar 84,98 pada siklus II sebesar

87,76 terdapat kenaikan 2,78.

dan siklus II selanjutnya disajikan

Perkembangan skor hasil

penilaian menulis teks berita siklus I

Bagan 1. Perkembangan Skor Hasil Penilaian Menulis Teks Berita Siklus I dan Siklus II.

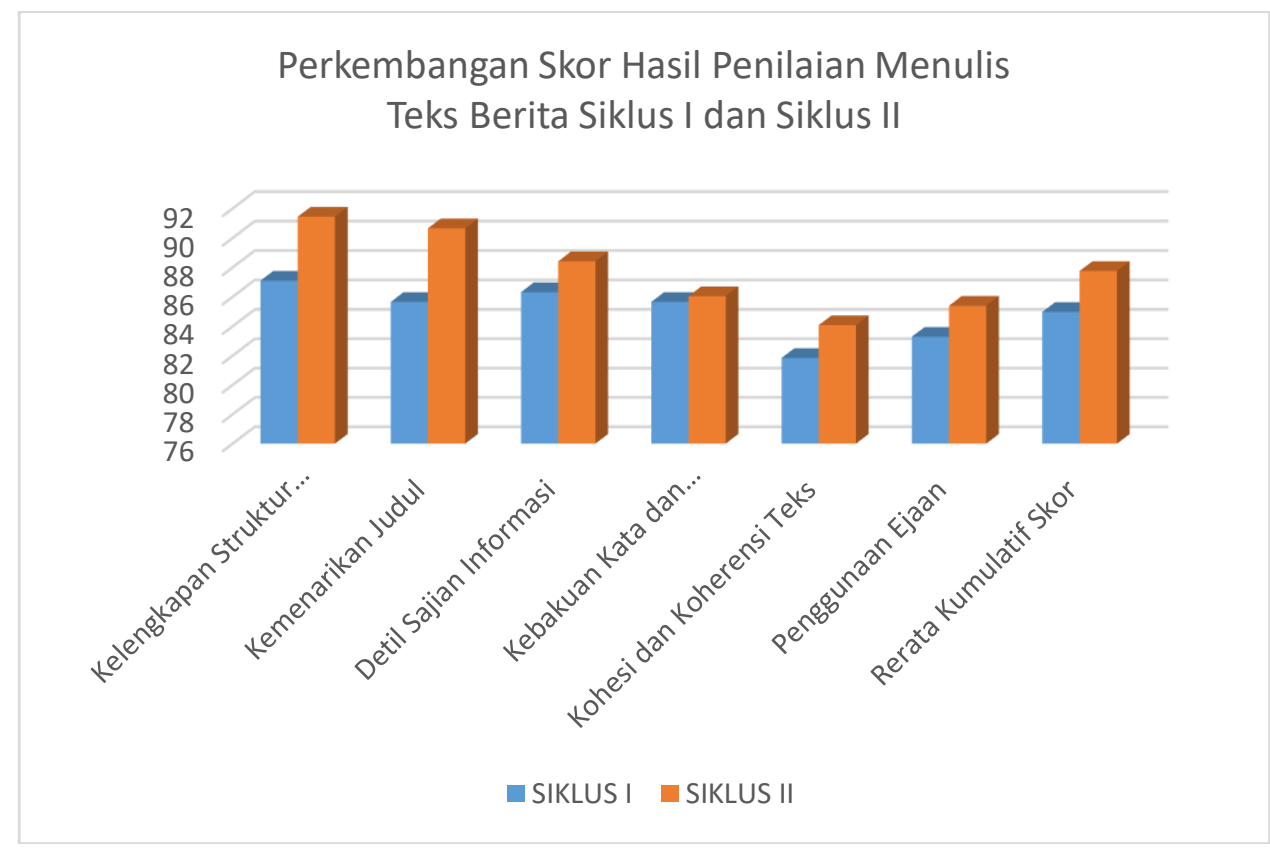

Perkembangan rerata skor I, dan siklus II disajikan dalam tabel 4 kemampuan menulis teks berita dan berikut.

pencapaian KKM pada kondisi awal, siklus

Tabel 4. Perkembangan Rerata Skor Kemampuan Menulis Teks Berita dan Pencapaian KKM padaKondisi Awal, Siklus I, dan Siklus II

\begin{tabular}{clcccc}
\hline & & Kondisi & & & \\
No & Uraian & Awal & Siklus I & Siklus II & Keterangan \\
\hline 1 & Rerata Skor & 77,33 & 84,98 & 87,76 & Naik \\
2 & Pencapaian KKM & 68,42 & 78,95 & 100 & Naik
\end{tabular}

Dari tabel 4 dapat diketahui 77,33 pada siklus I 84,98 terdapat perkembangan rerata skor kemampuan kenaikan 7,65. Pada siklus II rerata skor menulis teks berita dan pencapaian KKM kemampuan menulis teks berita sebesar pada kondisi awal, siklus I, dan siklus II. 87,76 terdapat kenaikan 2,78 dari siklus I. Rerata skor pada kondisi awal sebesar Pencapaian KKM pada kondisi awal 
Agung Pramujiono, Fadhilah. Penerapan Model STAD Berbantuan....

Halaman 1-14

Jurnal Belajar Bahasa, ISSN 2502-5864, E-ISSN 2503-0329

Volume 4, No. 1, Februari 2019

sebesar $68,42 \%$. Pada siklus I pencapaian

Selanjutnya perkembangan rerata skor KKM sebesar 78,95, terdapat kenaikan kemampuan menulis teks berita dan sebesar 10,53\% dari kondisi awal. Pada pencapaian KKM disajikan dalam bagan 2 siklus II pencapaian KKM sebesar $100 \%$ berikut.

terdapat kenaikan sebesar 21,05\%.

Bagan 2. Perkembangan Rerata Skor Kemampuan Menulis Teks Berita dan Pencapaian KKM

\section{Perkembangan Rerata Skor Kemampuan Menulis \\ Teks Berita dan Pencapaian KKM}

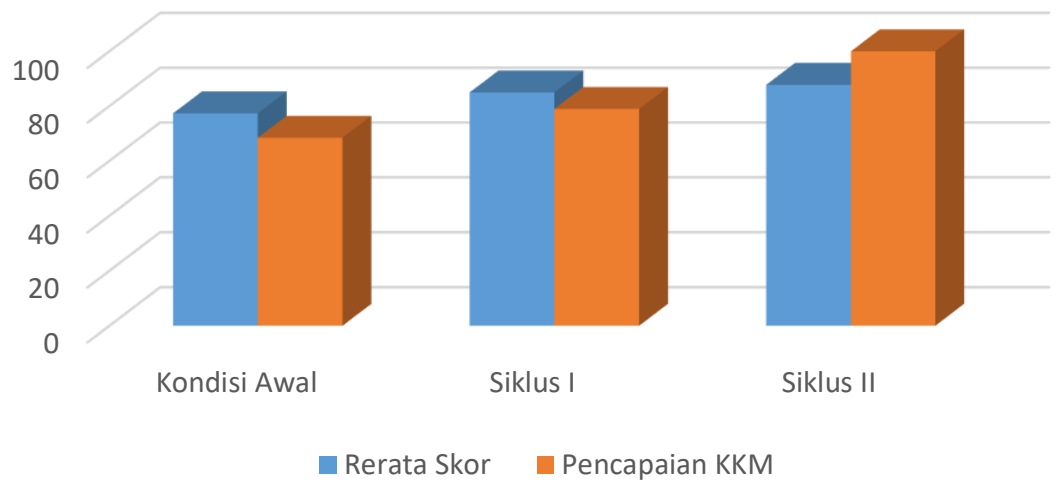

Berdasarkan hasil analisis data di atas kooperatif mendorong peserta didik untuk dapat diketahui bahwa penerapan model bekerja sama dengan anggota kelompok STAD berbantuan media data informasi lain dengan lebih baik. Hal ini sejalan dari internet dapat meningkatkan dengan pendapat Slavin (1995) yang kemampuan menulis berita peserta didik menyatakan bahwa pembelajaran kelas VIII-K SMPN 22 Surabaya. Ini kooperatif membantu peserta didik dalam membuktikan bahwa dengan penerapan berlatih menerima perbedaan dan bekerja model STAD yang menekankan pada kerja sama dalam kelompok dengan lebih baik sama dan kekompakan antarpeserta didik dapat meningkatkan kemampuan menulis dalam mencapai tujuan pembelajaran teks berita. Hal tersebut sejalan dengan yang ditargetkan. Temuan ini juga menguatkan hasil penelitian Elisa, apa yang dikemukakan oleh Arends (1997) bahwa penerapan pembelajaran Matsum, dan Warneri (2015); Sumarni dan Susanti (2016), dan Hastuti (2017) 
Agung Pramujiono, Fadhilah. Penerapan Model STAD Berbantuan....

Halaman 1-14

Jurnal Belajar Bahasa, ISSN 2502-5864, E-ISSN 2503-0329

Volume 4, No. 1, Februari 2019

yang telah membuktikan bahwa internet dapat meningkatkan kemampuan penerapan model STAD dapat menulis berita peserta didik kelas VIII-K meningkatkan hasil belajar SMPN 22 Surabaya.

mahasiswa/siswa.

Dampak pengiring dari penerapan model STAD berbantuan media data dari internet ini adalah (1) peserta didik mampu berkolaborasi dan bekerja sama dengan anggota kelompok dalam menyelesaikan tugas; (2) peserta didik dapat belajar mencari informasi, memilih informasi, dan menilai informasi sebelum menginformasikan kembali kepada orang lain;(3) peserta didik mau berbagi informasi dan membantu peseerta didik lain yang mengalami kesulitan; dan peserta didik belajar menghargai pikiran dan karya peserta didik yang lain.

\section{PENUTUP}

Berdasarkan hasil analisis data diketahui adanya peningkatan rerata skor untuk setiap aspek indikator penilaian kemampuan menulis teks berita dan rerata kumulatif aspek dari kondisi awal, siklus I, dan siklus II. Persentase pencapaian KKM dari kondisi awal, siklus I, dan siklus II juga mengalami peningkatan. Dengan demikian dapat disimpulkan penerapan model STAD berbantuan media data informasi dari

\section{DAFTAR RUJUKAN}

Arends, R.I. 1997. Classroom Instruction and Management. USA: McGraw Hill.

Elisa, S., Matsum, J.H., dan Warneri. 2015. “Efektivitas Penerapan Model STAD untuk Meningkatkan Hasil Belajar Siswa IX AK SMK" dalam jurnal.untan.ac.id/index.php/jpdpb/ article diunduh 20 September 2018 Pkl 20.00.

Kusumaningrat, $\mathrm{H}$. dan Kusumaningrat, P. 2006. Jurnalistik Teori \& Praktik. Bandung: PT Remaja Rosdakarya. Hastuti, E.F. 2017. “Penerapan Model Pembelajaran Kooperatif Tipe Student Teams-Achievement Division (STAD) untuk Meningkatkan Kemampuan Berpendapat" dalam https://ejournal.stkipmpringsewuIpg.ac.id/index.php/pesona/article/ diunduh 20 September 2018 Pkl 20.15 .

Nur, M. 2005. Pembelajaran Kooperatif. Jakarta: Depdiknas.

Pramujiono, A. 2010. Menulis PTK itu Gampang: dari Teori sampai Praktik. Surabaya: Adi Buana University Press. Slavin, R.E. 2008. Cooperative Learning Theory, Research, and Practice. Boston: Allyn and Bacon. Sumarni dan Susanti, N. 2016.

"Penerapan metode pembelajaran kooperatif tipe STAD untuk meningkatkan hasil belajar 
Agung Pramujiono, Fadhilah. Penerapan Model STAD Berbantuan....

Jurnal Belajar Bahasa, ISSN 2502-5864, E-ISSN 2503-0329

Volume 4, No. 1, Februari 2019

mahasiswa pada mata kuliah

Perencanaan Pembelajaran ekonomi

di STKIP PGRI SUMBAR" dalam

Economica Journal Economic and

Economical Education Vol 4 No. 1

(109-123) Tahun 2016 dalam

https://ejournal.stkipmpringsewu-

Ipg.ac.id/index.php/pesona/article/

diunduh 20 September 2018 Pkl

20.30 .
Suyanto dan Jihad, A. 2013. Menjadi Guru

Profesional Strategi Meningkatkan

Kualifikasi dan Kualitas Guru di Era

Global. Jakarta: Esensi.

Trianto.2009. Mendesain Model

Pembelajaran Inovatif-Progresif.

Jakarta: Kencana Prenada Media

Grup. 